SPECIAL DISTRIBUTION

Th1s document consists of $\frac{15}{106}$ Pages, Number $\frac{67}{6}$ of

\title{
PRECIPITATION OF NEPTUNIUM PEROXIDE
}

Title Unclaselfled

\section{by}

Glenn A. Burney and Ernest K. Dukes

$$
\text { July } 1961 .
$$
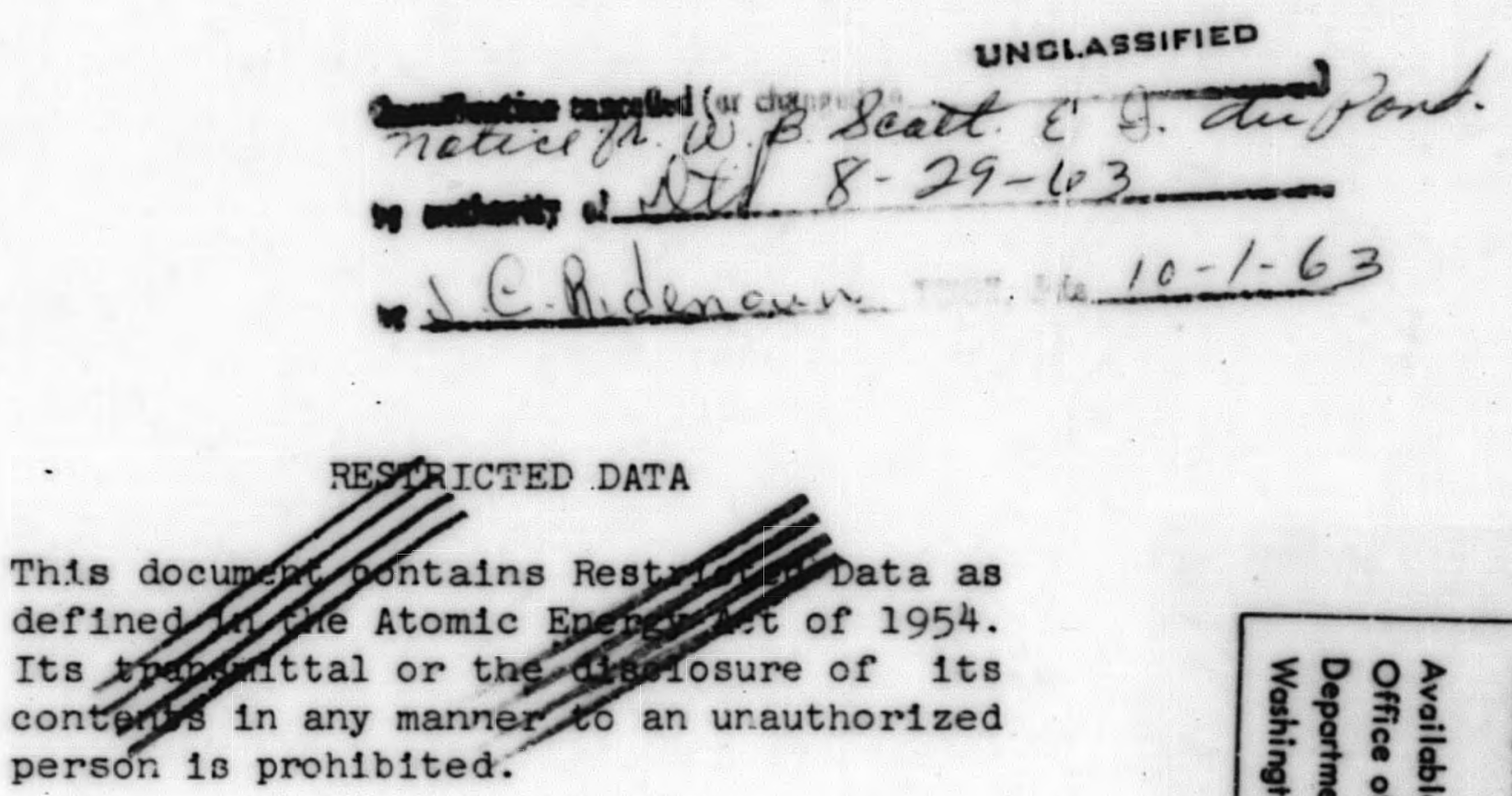

E. I. du Pont de Nemours \& Co. Explosives Department - Atom1c Energy D1vision Technical D1v1sion - Savannah R1ver Laboratory

\section{Printed for}

The United States Atom1c Energy Comm1ssion

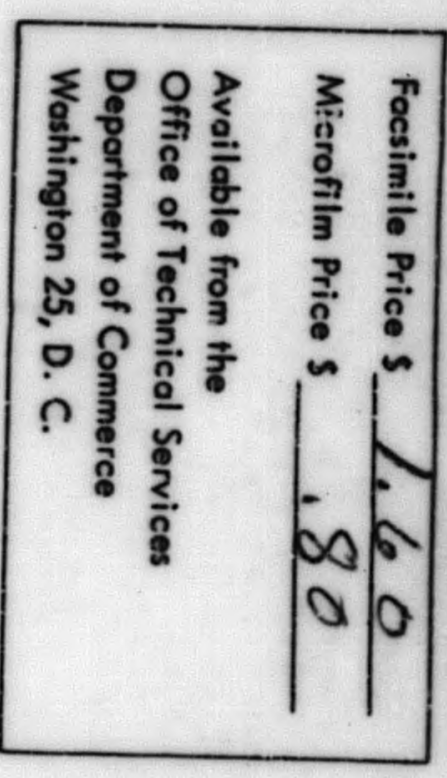




\begin{abstract}
Optir.um conditions were determined for the precipitation of neptunium(IV) peroxide from nitric ac1d solutions. The results indicate that the precipitation could be applied successfully on a plant scale.

Datc are presented for the solub1lity of neptunlum peroxide in solutions of nitric ac1d and hydrogen peroxide. The solub1lity $1 \mathrm{~s}$ less than $10^{-4} \mathrm{M}$ in 1.5 to $2.5 \mathrm{M}$ n1tric ac1d contalning $4.5 \mathrm{M}$ hydrogen peroxide. Two crystalline modifications of the peroxide were prepared; these two crystalline structures were s1milar to structures previously reported for plutonium peroxide.
\end{abstract}

\title{
UNCLASSFFED
}

$-2-$ 


\section{CONTENTS}

$\underline{\text { Page }}$

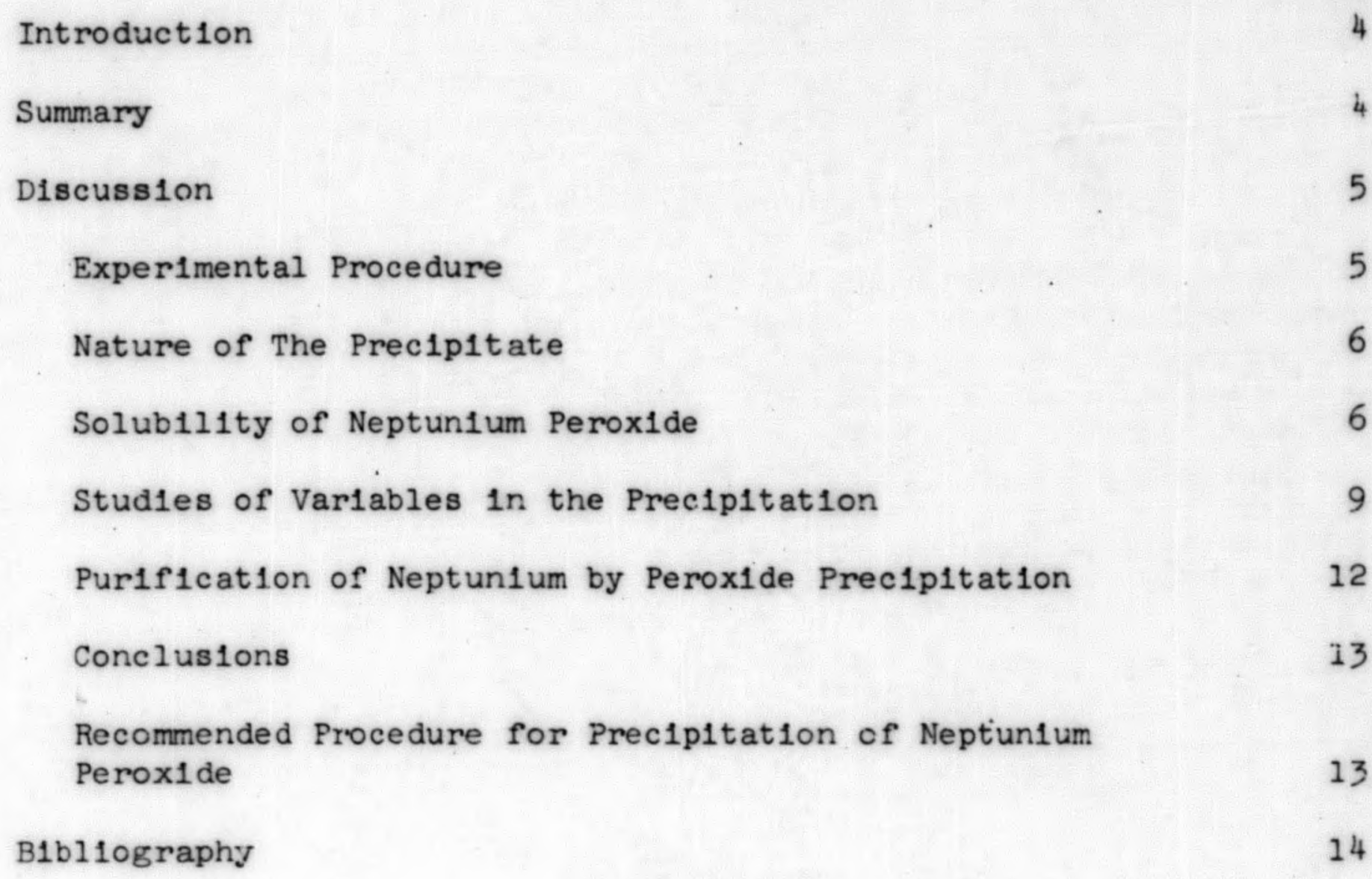

\section{LIST OF FIGURES}

\section{F1gure}

1 Solub1lity of Neptunium Peroxide as a Function of N1tric Ac1d Concentration

2 Solub1lity of Neptunium Peroxide as a Function of Hydrogen Peroxide Concentration

4

4

5

5

6

6

9

12

13

14

.

9 


\section{PRECIPITATION OF NEPTUNIUM PEROXIDE}

\section{INTRODUCTION}

Neptunium may be 1 solated from nitric ac1d solutions by a variety of routes. The pree1p1tation of neptunium( $\pi V)$, oxalate $1 \mathrm{~s}$ an attractive method that has been explnred thoroughly and applied successfully on a plant scale $(1 !$. In contrast, the precipitation of neptunium(IV) peroxide has not been extensively studied, although the analoguus plutonium system has recelved considerable attention and the method has been applied on a production scale ${ }^{(2)}$.

La Chapelle, Magnusson, and H1ndman(3) reported that a colorless-to-wh1te flocculent prec1p1tate of neptunium(IV) w1th a solub1lity of $100 \mathrm{mg}$ of neptunium per 11 ter was formed in $0.8 \mathrm{M} \mathrm{HNO}_{3}-3 \mathrm{M} \mathrm{H}_{2} \mathrm{O}_{2}$ solution. However, when a solution of neptunium(VI) in $0.5 \mathrm{M} \mathrm{HNO}_{3}$ wa.s made $1.5 \mathrm{M}$ in $\mathrm{H}_{2} \mathrm{O}_{2}$, the neptunium(VI) was rapldly reduced to (V), but reduction to (IV) did not take plave and no prec1p1tation occurred. Katz and Seaborg $\left.{ }_{4}\right)$ observed that neptunium solutions form an 1nsoluble prec1p1tate upon addition of peroxide, but they assumed that this precipitate was a derivative of the (VI) rather than the. (IV) state.

Th1s study was undertaken to elucidate the chemistry of neptunium peroxide formation and to evaluate the precipitation as a plant process. For th1s application optimum conditions were sought for producing a sol1d that would filter easily and have a m1n1mum solub1lity.

\section{SUMMARY}

Neptunium(IV) peroxide was prec1p1tated read1ly from solutions contalning $\mathrm{Np}(\mathrm{IV}),(\mathrm{V})$, or (VI) in $3 \mathrm{M} \mathrm{n} 1 \mathrm{tr} 1 \mathrm{c}$ ac1d by the addition of hydrogen peroxide. The $\mathrm{h} 1$ zher valence states were rapldily reduced to the (IV) state, wh1ch was prec1pitated by the hydrogen peroxide in the strong ac1d solutions. The prec1p1tate was gray-purple, and the precipltation did not progress through the highly colored, soluble peroxy complexes that are characteristic in the formation of plutonium peroxide ${ }^{(5)}$.

Two crystalline forms of neptunium(IV) peroxide were prepared that were quite similar to the two forms of plutonium peroxide found under similar conditions $(6)$. The crystalline form derived from solutions of low ac1d1ty (IM) was face-centered cub1c $(a=17 \AA)$, while the structure formed at higher ac1dity $(4 M)$ was nearly 1 dent1cal with the hexagonal form of plutonium peroxide.

The solub1lity of neptunium peroxide at $23^{\circ} \mathrm{C}$ varled as a function of the concentration of $\mathrm{n} 1 \mathrm{tr} 1 \mathrm{c}$ ac1d and hydrogen peroxide. A minimum solub1lity of approximately $10^{-4} \mathrm{M}$ neptunium occurred in solutions contalning 1.5 to $2.5 \mathrm{M} \mathrm{HNO}_{3}$ and $4.5 \mathrm{M} \mathrm{H}_{2} \mathrm{O}_{2}$. 
Neptunium(IV) peroxide with good f1ltration characteristics was formed w1th losses of less than $0.2 \%$ of the neptunium to the f1ltrate when the ac1d concentration, the mixing effi:1ency, and the peroxide aldition rate were controlled.

The precipitation of neptunium peroxide did not effectively separate neptunium from plutonium, protactinium, z1rcorium, or nioblum.

\section{DISCUSSION}

\section{EXPERIMENTAL PROCEDURE}

\section{PREPARATION OF REAGENTS}

A stock solution of neptunium-237 was prepared by anion exchange. The anionic nitrate complex of neptunium(IV) was absorbed from $8 \mathrm{M}$ nitric ac1d on a column of "Dowex" 1-X4 resin, and the resin was then washed with ten bed volumes of 3M ritric ac1d. Solutions of neptunium(IV) were obtained by eluting neptunium from the column with $0.35 \mathrm{M}$ nitric acid that contained $0.05 \mathrm{M}$ hydrazine as an ant1oxidant. Neptunium(V) was obtalned by eluting with $0.35 \mathrm{M}$ nitric ac1d and heating the eluate to $55^{\circ} \mathrm{C}$ for 30 minutes. The valence state of neptunium in each solution was verifled by spectrophotometric examination ${ }^{(7)}$.

A $30 \%$ solution of reagent grade hydrogen peroxide that was stabilized w1th sodium stannate was used for all experiments except in one prec1pitation for which a 55\% solution was used.

The nydrazine used was a $35 \%$ aqueous solution produced by Fetz Laboratories and marketed under the trade name "Hyzeen".

\section{SOLUBILITY STUDIES}

Prec1pitates of neptunium peroxide were prepared by adding al1quots of neptunium(IV) solution to m1xtures of nitric ac1d and hydrogen peroxide. The prec1pitate was removed by filtration, washed with alcohol, and alr dried. The peroxy-oxygen content of the precipltates was determined by 1odometric titration.

Each solubllity value was determined several times, starting with the solld precipitate or with a solution of $\mathrm{Np}(\mathrm{IV})$. Results from the two methods agreed. Equilibrium was reached in less than 20 hours starting w1th solutions of neptunium, and in less than 6 hours starting with solld precipitates: For the determinations a solution was prepared with the desired concentration of hydrogen peroxide and nftric ac1d. Enough neptunium stock was added to give the solution the composition desired after prec1pitation, or enough sol1d neptunium peroxide was added to ensure an excess during equilibration. The sample was held at $23^{\circ} \mathrm{C}$ and agitated. Each sample was centrifuged at regular intervals, then an aliquot of the supernate was analyzed for neptunium, hydrogen 
peroxide, and $.215 \mathrm{rc}$ ac1d. The concentration of neptinium was determined by alpha counting. The concentration of $\mathrm{H}_{2} \mathrm{O}_{2}$ was determined by t1trating with standard $\mathrm{KMnO}_{4}$ solution, and the concentration of $\mathrm{HNO}_{3}$ was determined by titrating with standard NaOH solution.

\section{PRECIPIT ATION STUDIES}

In studying the effect of variables in the precipltaticn, the anion exchange eluate was adjusted to 35 grams of neptunium per liter and to the desired ac1d concentration by adding $n 1 t r 1 c$ ac1d. Other reagents were added as required and the temperature was adjusted to the desired value; then an equal volume or $30 \%$ hydrogen peroxide was added to the agltated neptunium solution. After addition of hydrogen peroxide, the slurry was digested at a concrolled temperature and filtered through a medium porosity frltted glass disc. The temperature and the times were varled for addition of hydrogen peroxide and for digestion.

The filtration characteristics of the prec1pitates were compared by measuring "filtration factors". The filtration factor was defined as the ratio of the time required to filter a given slurry through a given filter to the time required to pass an equal volume of water through the same filter under the same conditions.

\section{NATURE OF THE PRECIPITATE}

Preliminary studies showed that the neptunium(IV) peroxide precipitate was gray-purple, and that the prec1pitation did not progress through the highly colored, soluble peroxy-complexes that are characteristic of the formation of plutonium peroxide $(5)$.

Two crystalline forms of neptunium peroxide were prepared that were quite similar to the two forms of plutonium peroxide( 6$)$. The crystals formed in solutions of low acldity, about $1 \mathrm{M}$, were shown by $\mathrm{X}$-ray diffraction to be face-centered cubic with a unit cell dimension $a_{0}=17 \AA$. The crystals formed in solutions of high acidity, about $4 \mathrm{M}$, were nearly 1dentical with the hexagonal form of plutonium peroxide.

The peroxy-oxygen t.o neptunium ratio was 2.9 for the cubic form, and 3.3 for the hexagonal form. The values reported for the two forms of piutonium perox1de were 3.04 and 3.34 , respect1vely ${ }^{(6)}$.

\section{SOLIJBILITY OF NEPTUNIUM PEROXIDE}

The solubllity of neptunium peroxide at $23^{\circ} \mathrm{C}$ varled as a function of the concentrations of nitric acld and hydrogen peroxide. The solublity curve as a function of ac1d concentration is shown in F1gure 1; the eurve may be considered to consist of three parts. Between 0.1 and $1.0 \mathrm{M}$ nitric ac1d, the solubllities are difficult to reproduce, but appear to decrease w1th approximately an 1nverse f1rstpower dependence on ac1d concentration. Between 1.0 and $2.5 \mathrm{M} \mathrm{n} 1 \mathrm{tr} 1 \mathrm{c}$ 
ac1d, the solub1lity is essent1ally independent of the ac1d concentration. At ac1d concentrations greave: than 3M, the solubility increases with an approximate four.th-power dependence on ac1d concentration.

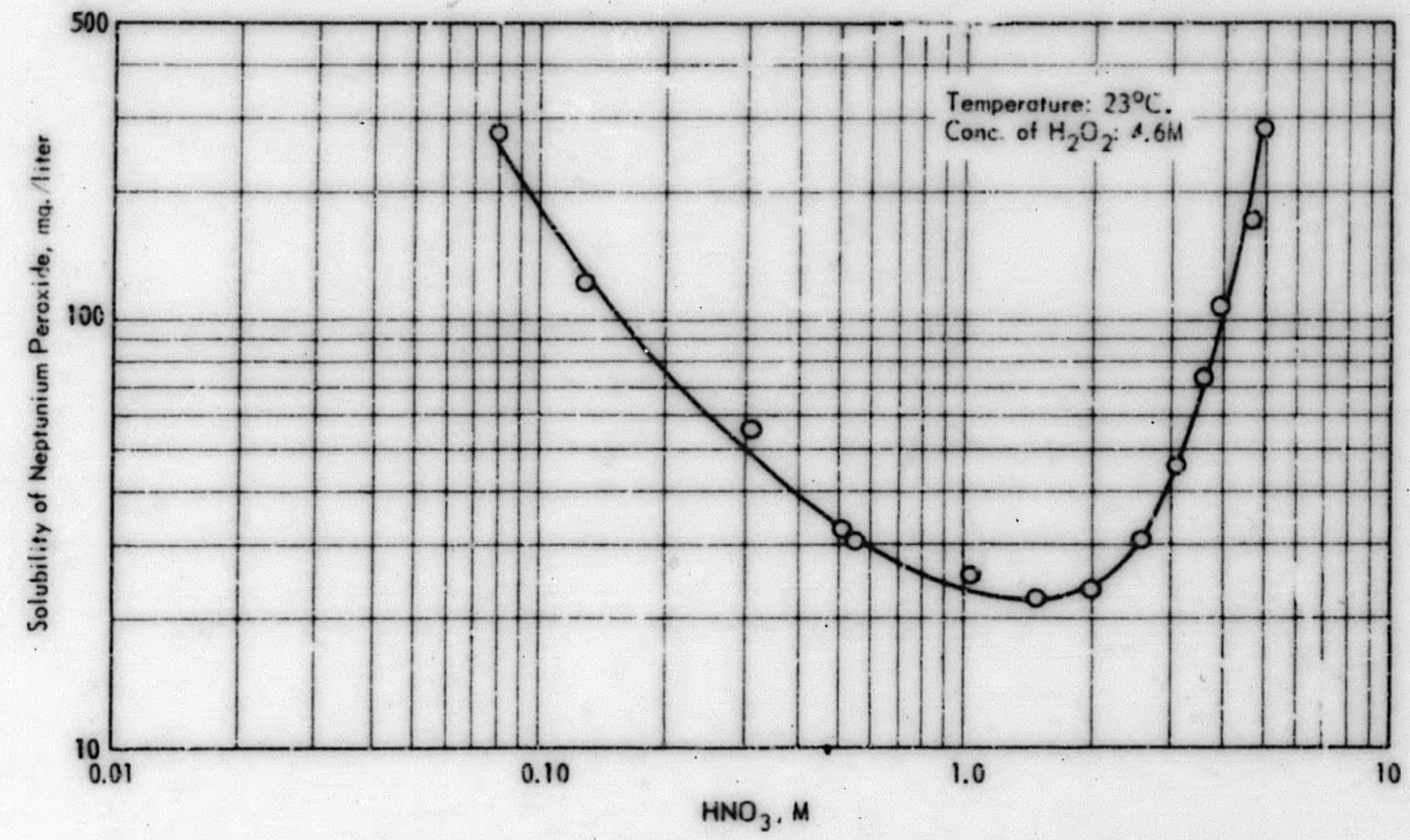

FIG. I SOLUBILITY OF NEPTUNIUM PEROXIDE AS A FUNCTION OF NITRIC ACIO CONCENTRATION

Only at ac1d concentrations greater than $2.5 \mathrm{M}$ were the solubilities readily reproducible. In the concentration range of 3 to $5 \mathrm{M}$ acid, the following reaction describes the approximate fourth-power aced dependence.

$$
\mathrm{Np}(\mathrm{IV})+2 \mathrm{H}_{2} \mathrm{O}_{2}=\mathrm{NpO}_{4}+4 \mathrm{H}^{+}
$$

The experimental data for this range of acid concentration are consistent with the expression

$$
\mathrm{S}=9.93 \frac{\left[\mathrm{H}^{+}\right]^{4}}{\left[\mathrm{H}_{2} \mathrm{O}_{2}\right]^{2}}
$$

where $S$ is neptunium concentration in mililgnans per 11 ter, and $\left[\mathrm{H}^{+}\right]$ and $\left[\mathrm{H}_{2} \mathrm{O}_{2}\right.$ ] are hydrogen $10 \mathrm{n}$ and hydrogen peroxide concentrations expressed in molarity. In nitric ac1d solutions more concentrated than $2.5 \mathrm{M}$, cnly the hexagonal modification of neptunium peroxide was formed. In fact it was shown that the low-ac1d, or cubic form, when added to 2.5 to $5 \mathrm{M}$ ac1d was converted to the hexagonal form in less 
than 24 hours, the time of equilibration in the solubility determinations. Thus, the solubility measurements in 2.5 to $5 \mathrm{M}$ ac1d were not complicated by the presence of more than one crystalline form. Furthermore, at these ilgher ac1dities reduciton of $\mathrm{Np}(\mathrm{VI})$ and $\mathrm{Np}(\mathrm{V})$ to $\mathrm{Np}$ (IV) by hydrogen peroxide was guite rapld and complete. For this reason, the solubllity measurements were also not complicated by the presence of traces or the higher valence states of neptunium. A comparison of experinental and calculated solubilities at the higher acld strengtis 1s shown in the table.

\section{Solub1? ity of $\mathrm{Np}$ Peroxide at $23^{\circ} \mathrm{C}$}

\begin{tabular}{|c|c|c|c|}
\hline \multirow[b]{2}{*}{$\mathrm{HNO}_{3}, \mathrm{M}$} & \multirow[b]{2}{*}{$\mathrm{H}_{2} \mathrm{O}_{2}, M$} & \multicolumn{2}{|c|}{ Solubility, mg $\mathrm{Np} / \mathrm{l}$} \\
\hline & & Experimenta? & Calculated \\
\hline 2.57 & 4.6 & 30 & 21 \\
\hline 3.09 & 4.6 & 46 & 43 \\
\hline 3.62 & 4.6 & 72 & 79 \\
\hline 3.84 & 4.6 & 108 & 98 \\
\hline 4.68 & 4.6 & 2.18 & 229 \\
\hline 5.00 & 4.5 & 282 & 293 \\
\hline 2.5 & 1.8 & 113 & 120 \\
\hline 2.5 & 2.8 & 54 & 49 \\
\hline 2.5 & 3.7 & 32 & 28 \\
\hline 2.5 & 4.7 & 21 & 18 \\
\hline 2.5 & 6.5 & 11 & 9 \\
\hline
\end{tabular}

Below $2 M$ ac1d concentration, the measured solubilities were erratic and difficult to reproduce. It was demonstrated that the hexagonal form of neptunium peroxide, wien added to $1 \mathrm{M}$ ac1d, was not completely converted to the cublc form in 24 hours. Thus, there is the possibility that both cub1c and hexagonal forms of the peroxide were present at the lower acld concentrations and that the m1xed crystal forms may have contributed to the errat1c solub1lity data. Another potent1al dificulty in achieving reproducible results was the slow reduction of $\mathrm{Np}(\mathrm{V})$ to $\mathrm{Np}$ (IV) by hydrogen peroxide at low ac1d strength. The neptunium measured in the solution after equilibration may have contalned $\mathrm{Np}(\mathrm{V})$ as well as $\mathrm{Np}(\mathrm{IV})$. The solubility data shown in Figure 1 in the ac1d range from 0.1 to $2.5 \mathrm{M}$ are minimum values; experimental values were often two to three times greater than the values given.

The sollib1lity of neptunium peroxide decreases with increasing concentrations of hydrogen peroxide. There is approximately an inverse 1.84 -power dependence on hydrogen peroxide concentration $1 \mathrm{n} 2.5 \mathrm{M}$ nitric ac1d. The data are shown in F1gure 2. 


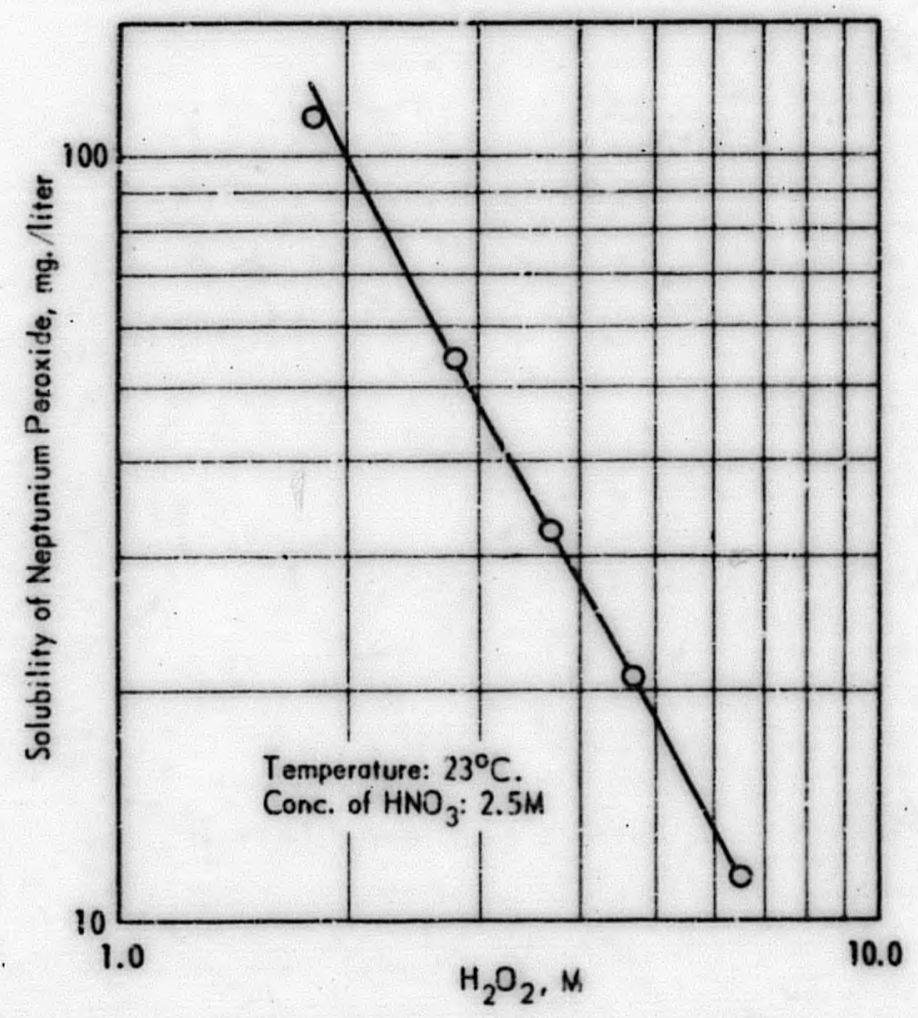

FIG. 2 SOLUBILITY OF NEPTUNIUM PEROXIDE AS A FUNCTION OF HYROGEN PEROXIDE CONCENTRATION

\section{STUDIES OF VARIABLES IN THE PRECIPITATION}

\section{EFFECT OF ACID CONCENTRATION AND VALENCE STATE OF NEPTUNIUM}

In the precipitation, the optimum final acidity for low solubility and good flitration characteristics was 1.5 to $2.5 \mathrm{M}$; this is consistent w1th the equilibrium solub1lity measurements described above. Some typical data for precipitations at different ac1dities are shown in the following table. In the opt1mum range of ac1dity, the losses of neptunium to the filtrate were near the equilibrium solubility values.

Effect of Ac1d Concentration on Solub111ty and F11tration Characterist1cs

Feed: $\quad 35 \mathrm{mg} \mathrm{Np}(\mathrm{V}) / \mathrm{ml}$ in varying concentrations of HNO, conditions: An equal volume of $30 \mathrm{H}_{2} \mathrm{H}_{2}$ added at a controlled rate over 2 hours at $23^{2} \mathrm{C}$ D1gestion at $5^{\circ} \mathrm{C}$ for 30 m1nutes

$\begin{array}{ccc}\begin{array}{c}\text { Concent.ration of } \\ \text { HNO }_{3} \text { 1n F11trate }\end{array} & \begin{array}{c}\text { Filtration } \\ \text { Factor }(\mathrm{a})\end{array} & \begin{array}{c}\text { Concentration of } \mathrm{Np} \\ \text { 1n F1ltrate, mg/1 }\end{array} \\ 0.7 & 7.0 & 710 \\ 1.2 & 5.0 & 93 \\ 1.8 & 6.8 & 27 \\ 2.2 & 5.7 & 34 \\ 2.8 & 8.8 & 40 \\ 3.6 & 5.5 & 92\end{array}$

(a) A flitration factor $1 \epsilon s$ than about 1018 adequate for operation on a production scale. 
The solubility of neptunium and the filtration characterist1cs of the prec1pitate were not dependent on the valence state of neptunium in the feed solution, as long as the ac1d concentration was in the optimum range. This may be seen by comparing the results in the above table where the feed contained $\mathrm{Np}(\mathrm{V})$, with the results in the following table, where stab1lized $\mathrm{Np}$ (IV) was present in the feed. In the two experiments at acldities less than $1 \mathrm{M}$, the loss of neptunium to the flltrate was h1gher when the feed was $\mathrm{Np}(\mathrm{V})$. because of incomplete reduction to the (IV) state.

\section{Effect of Np Valence on Solub1l1ty}

Feed: $\quad 35 \mathrm{mg} \mathrm{Np}$ ( IV) $/ \mathrm{ml}-0.04 \mathrm{M} \mathrm{N}_{2} \mathrm{H}_{4}$ in vary1ng concentrations of $\mathrm{HNO}_{3}$.

Conditions: Same as in previous table

Concentration of
$\mathrm{HNO}_{3}$ in F1ltrate

0.8

1.2

2.25

3.4

\section{Filtration Factor}

Concentration of $\mathrm{Np}$ in Filtrate, $\mathrm{mg} / \mathrm{l}$

\section{$9 \cdot 5$}

6.3

101

8.5

5.7

77

42

71

\section{EFFECT OF HYDROGEN PEROXIDE CONCENTRATION}

The solubllity of neptunium peroxide in 2.2M nitric ac1d was decreased approximately $30 \%$ by 1ncreasing the concentration of hydrogen peroxide from 4.6 to $6.9 \mathrm{M}$. The two concentrations of hydrogen peroxide were attalned by adding $30 \%$ hydrogen peroxide for the lower concentration and $50 \%$ hydre jen peroxide for the higher concentration.

Effect of Hydrogen Feroxide Concentration on Solubility and F1ltration Characteristics

Feed: $35 \mathrm{mg} \mathrm{Np}(\mathrm{IV}) / \mathrm{ml}$ in $\mathrm{HNO}_{3}$

Conditions: An equal volume of $\mathrm{H}_{2} \mathrm{O}_{2}$ added at a controlled rate over 2 hours at $23^{\circ} \mathrm{C}$ Digestion at $5^{\circ} \mathrm{C}$ for 30 minutes

\section{Composition of Filtrate}

$4.6 \mathrm{M} \mathrm{H}_{2} \mathrm{O}_{2}-2.2 \mathrm{M} \mathrm{HNO}_{3}$

$6.9 \mathrm{M} \mathrm{H}_{2} \mathrm{O}_{2}-2.2 \mathrm{M} \mathrm{HNO}_{3}$
F11tration Factor

5.6

$7 \cdot 3$
Concentration of $\mathrm{Np}$ in Filtrate, $\mathrm{mg} / 1$

39

26 


\section{EFFECT OF SULFATE}

The addition of $0.05 \mathrm{M}$ sulfate to the neptunlum nitrate feed solution improved the filtration characteristics of the precipitate and decreased the time required for filtration by approximately $40 \%$. This same effect has been observed in the precipitation of plutonium peroxide. Addition of sulfate did not appreclably affect the solubility of neptunium.

Effert of Sulfate on Solub1lity and F1itration Character1st1cs

Feed: $\quad 35 \mathrm{mg} \mathrm{Np}(\mathrm{V}) / \mathrm{ml}$ in $\mathrm{HNO}_{3}$ Conditions: An equal volume of $30 \% \mathrm{H}_{2} \mathrm{O}_{2}$ added at a controlled rate over 2 hours at $23^{\circ} \mathrm{C}$

\begin{tabular}{|c|c|c|c|c|}
\hline & $\begin{array}{c}\text { Feed } \\
\text { Compos1tion }\end{array}$ & $\begin{array}{l}\text { D1gest1on } \\
\text { Cond1t1ons }\end{array}$ & $\begin{array}{l}\text { F1ltration } \\
\text { Factor } \\
\end{array}$ & $\begin{array}{c}\text { Concentration of } \mathrm{Np} \text { in } \\
\text { F1ltrate, } \mathrm{mg} / 1 \\
\end{array}$ \\
\hline $3 \mathrm{M}$ & $\mathrm{HNO}_{3}-0.05 \mathrm{M} \mathrm{SO}_{4}$ & 30 inin at $25^{\circ} \mathrm{C}$ & 3.6 & 38 \\
\hline $3 M$ & $\mathrm{HNO}_{3}-\mathrm{NC} \mathrm{SO}_{4}$ & $30 \mathrm{~min}$ at $23^{\circ} \mathrm{C}$ & 5.7 & 44 \\
\hline $3 \mathrm{M}$ & $\mathrm{HNO}_{3}-0.05 \mathrm{M} \mathrm{SO}_{4}$ & $30 \mathrm{~min}$ at $5^{\circ} \mathrm{C}$ & 3.8 & 25 \\
\hline & $\mathrm{HNO}_{3}-\mathrm{NO} \mathrm{SO}_{4}$ & $30 \mathrm{mln}$ at $5^{\circ} \mathrm{C}$ & 6.8 & 32 \\
\hline & $\mathrm{HNO}_{3}-0.05 \mathrm{M} \mathrm{SO}_{4}$ & $30 \mathrm{~m} 1 \mathrm{n}$ at $5^{\circ} \mathrm{C}$ & 4.0 & 41 \\
\hline $4 M$ & $\mathrm{HNO}_{3}-\mathrm{No} \mathrm{SO}_{4}$ & $30 \mathrm{~min}$ at $5^{\circ} \mathrm{C}$ & 5.7 & 34 \\
\hline
\end{tabular}

\section{EFFECT OF IRON}

Since the reduction of neptunium(V) to (IV) w1th ferrous sulfamate is rap1d and quant1tative in 3 to $4 \mathrm{M}$ nitric ac1d, an attempt was made to decrease the solubility of neptunium peroxide by adding this reductant. The flitrate losses were in actuality higher in the prec1pitations in which ferrous sulfamate was added. This is possibly explained by the catalyt1c oxidation of $\mathrm{Np}$ (IV) to the more soluble $\mathrm{Np}(\mathrm{V})$ by 1 ron(III), whish is produced by the oxidation of 1ron(II) by hydrogen peroxide. Some typlcal data are giver in the following table.

\begin{tabular}{|c|c|c|c|}
\hline \multirow[b]{2}{*}{ Feed Composition } & \multicolumn{3}{|c|}{$\begin{array}{l}\text { Feed: } 35 \mathrm{mg} \mathrm{Np} / \mathrm{ml} \text { in } \mathrm{HNO}_{3} \\
\text { Conditions: Equal volume of } 306 \mathrm{H}_{2} \mathrm{O}_{2}\end{array}$} \\
\hline & $\begin{array}{l}\text { Prec1p1tation } \\
\text { Cond1tions }\end{array}$ & $\begin{array}{l}\text { F11tration } \\
\text { Factor } \\
\end{array}$ & $\begin{array}{l}\text { Concentration of } \mathrm{Np} \\
\text { 1n F11trate, } \mathrm{mg} / 1\end{array}$ \\
\hline $\begin{array}{l}\mathrm{Np}(\mathrm{IV}) \text { in } 3 \mathrm{M} \mathrm{HNO} \\
0.05 \mathrm{M} \mathrm{Fe}\left(\mathrm{NH}_{2} \mathrm{SO}_{3}\right)_{2}\end{array}$ & $\begin{array}{l}\mathrm{H}_{2} \mathrm{O}_{2} \text { add1t } 10 \mathrm{On}: \\
30 \mathrm{~m} \text { in at } 17^{\circ} \mathrm{C}\end{array}$ & 6.1 & 47 \\
\hline $\begin{array}{l}\mathrm{Np}(\mathrm{TV}) \text { in } 3 \mathrm{M} \mathrm{HNO}_{3}- \\
\mathrm{No} \mathrm{Fe}\left(\mathrm{NH}_{2} \mathrm{SO}_{3}\right)_{2}\end{array}$ & $\begin{array}{l}\text { Digest1on: } 30 \mathrm{~min} \\
\text { at } 17^{\circ} \mathrm{C} \text { - Cooled to } \\
5^{\circ} \mathrm{C} \text { for flitration }\end{array}$ & 5.7 & 28 \\
\hline $\begin{array}{l}\mathrm{Np}(\mathrm{V}) \text { in } 4 \mathrm{MHNO}_{3}- \\
0.2 \mathrm{Me}\left(\mathrm{NH}_{2} \mathrm{SO}_{3}\right)_{2}\end{array}$ & $\begin{array}{l}\mathrm{H}_{2} \mathrm{O}_{2} \text { addition: } \\
2 \text { hours at } 23^{\circ} \mathrm{C}\end{array}$ & 6.5 & 71 \\
\hline $\begin{array}{l}\mathrm{Np}(\mathrm{V}) \text { in } 4 \mathrm{M} \mathrm{HNO}_{3}- \\
\text { No } \mathrm{Fe}\left(\mathrm{NH}_{2} \mathrm{SO}_{3}\right)_{2}\end{array}$ & $\begin{array}{l}\text { D1gestion: } 30 \mathrm{~min} \\
\text { at } 5^{\circ} \mathrm{C}\end{array}$ & 5.7 & 34 \\
\hline
\end{tabular}




\section{EFFECT OF TEMPERATURE}

The solub1lity of neptunium peroxide was decreased approximately 25\% by digesting and f1ltering at $5^{\circ} \mathrm{C}$ rather than at $23^{\circ} \mathrm{C}$. The filtration character1stics of the prec1pitate were not significantly affected by varying the temperature of digestion of the slurry.

\section{Effect of Temperature on Solub1lity and F1ltration Characteristics}

Feed: $35 \mathrm{mg} \mathrm{Np}(\mathrm{V}) / \mathrm{ml}$

Conditions: An equal volume of $30 \% \mathrm{H}_{2} \mathrm{O}_{2}$ added over 2 hours at $23^{\circ} \mathrm{C}$

\begin{tabular}{|c|c|c|c|}
\hline $\begin{array}{c}\text { Feed } \\
\text { Compos1t1on } \\
\end{array}$ & D1gest1on Conditions & $\begin{array}{c}\text { F1ltration } \\
\text { Factor } \\
\end{array}$ & $\begin{array}{l}\text { Concentration of } \mathrm{Np} \\
\text { In F1ltrate, } \mathrm{mg} / \mathrm{l}\end{array}$ \\
\hline $3 \mathrm{M} \mathrm{HNO}{ }_{3}$ & $30 \mathrm{~m} 1 \mathrm{n}$ at $23^{\circ} \mathrm{C}$ & 5.7 & 44 \\
\hline $3 \mathrm{M} \cdot \mathrm{HNO}_{3}$ & $30 \mathrm{~m} 1 \mathrm{n}$ at $5^{\circ} \mathrm{C}$ & 6.8 & 32 \\
\hline $4 \mathrm{M} \mathrm{HNO}_{3}$. & $30 \mathrm{~min}$ at $23^{\circ} \mathrm{C}$ & 6.7 & 43 \\
\hline $4 \mathrm{M} \mathrm{HNO}_{3}$ & $30 \mathrm{~min}$ at $5^{\circ} \mathrm{C}$ & 5.7 & 34 \\
\hline
\end{tabular}

\section{PURIFICATION OF NEPTUNIUM BY PEROXIDE PRE.CIPITATION}

The purification of neptunium that 1s atta1nable by peroxide precipitation was not studied extensively. It is expected that the separation from a number of cationic 1mpurities, such as 1ron, would be excellent, as 1t $1 \mathrm{~s}$ in the case of plutonium peroxide prec1pitation. The separation of neptunium from plutonium, z1rconlum, nlob1um, and protactinfum was measured and found to be poor. Plutonlum was carrled completely with the prec1pitate. $\mathrm{Pa}^{233}$, the daughter product of $\mathrm{Np}^{237}$ alpha decay, was carried to the extent of about $90 \%$ when present 1 n equ1librium ciuantities. About $30 \%$ of the $\mathrm{Zr}^{25}-\mathrm{Nb}^{95}$ present in tracer quantities was carried by the peroxide prec1pitate. 


\section{CONCLUSIONS}

Prec1p1tation of neptunium(IV) peroxide 1s an adequate method for plant use. Hydrogen peroxide convenlentiy reduces neptunium to the proper valence state for precipitation. When the acidity, the rate of peroxide addition, and the degree of mixing are carefully controlled, the properties of neptunium peroxide are quite similar to those of plutonium peroxide. The loss of neptunium to the filtrate approximates $10^{-4}$ molar.

\section{RECOMMENDED PROCEDURE FOR PRECIPITATION OF NEPTUNIUM PEROXIDE}

The following procedure is recommended for the precipltation of neptunium peroxide :

Feed Preparation: Adjust the ac1d concentration to 3 to $4 \mathrm{M}$ No valence adjustment is necessary.

Prec1p1tation: Maintain adequate mixing. Add an equal volume of $30 \%$ hyd:ogen peroxide at a controlled rate over a period of 90 minutes. Maintaln the temperature of the slurry at $18-25^{\circ} \mathrm{C}$.

D1gest1on: Cool the slurry to $8^{\circ} \mathrm{C}$ and hold at this temperature for 30 minutes.

F1ltration: F1lter as rap1dly as possible through a frit with a mean pore size of approximately 8 to $10 \mathrm{~m} 1 \mathrm{crons}$.

Wash: Wash the prec1p1tate as required for subsequent processing with a m1xed nitric ac1d - hydrogen peroxide solution.

Dry1ng: Dry as required for subsequent processing.

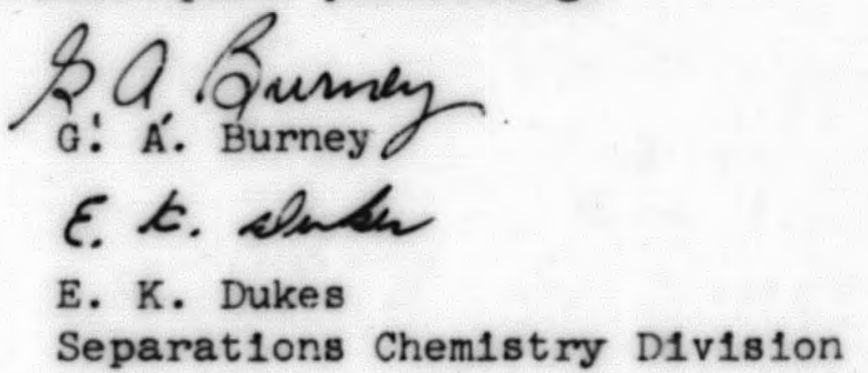




\section{BIELIOGRAPHY}

1. Porter, J. A. Prec1pitation of Neptunium Oxalate and Calc1nation to Neptunium Ox1de. E. I. du Pont de Nemours \& Co., Savannah Report DP-591 (to be published) (Secret).

2. Field; E. L., D. A. Orth, and J. H. Radke. "Production of Plutonium Metal from Aqueous Solut1ons". Paper No. 90, Presented at the 138th Nat1onal Meeting of the Amer1can Chem1cal Soc1ety, Nuclear Technology Sympos1um, New York C1ty, September 11-16, 1960. (to be published as part of a staff report in Ind. and Eng. Chem.)

3. LaChapel1e, T. J., L. B. Magnusson, and J. C. H1ndman. "Chem1stry of Neptun1um. F1rst Preparation and Solub1lities of Some Neptun1um Compounds 1n Aqueous Solut1ons". Paper 15.6. The Transuran1um Elements NNES IV-14B, New York: McGraw-H111 1st Ed. $(1949)$. 4. Katz, J. J. and G. T. Seaborg. The Chem1stry of the Act1nide
Elements. New York: W1ley, p. $291(1957)$.

5. Connick, R. E. and MaVey, "The Peroxy Complexes of Plutonlum (IV)". J. Am. Chem. Soc. 11, 1534-42 (1949).

6. Leary, J. A. Studies on the Preparation, Properties, and composition of Plutonium Peroxide. Los Alamos Sc1entific Leport LA-1913, 38 pp. (December 1954).

7. Dukes, E. K. and W. E. Shuler. Spectrophotometric Determination of M1xtures of Neptun1um (IV) and Neptun1um (V) in N1tr1c Ac1d Laboratory A A ken, S. C. AEC Researeh and Developent Report

\section{UNCLASSFIFED}

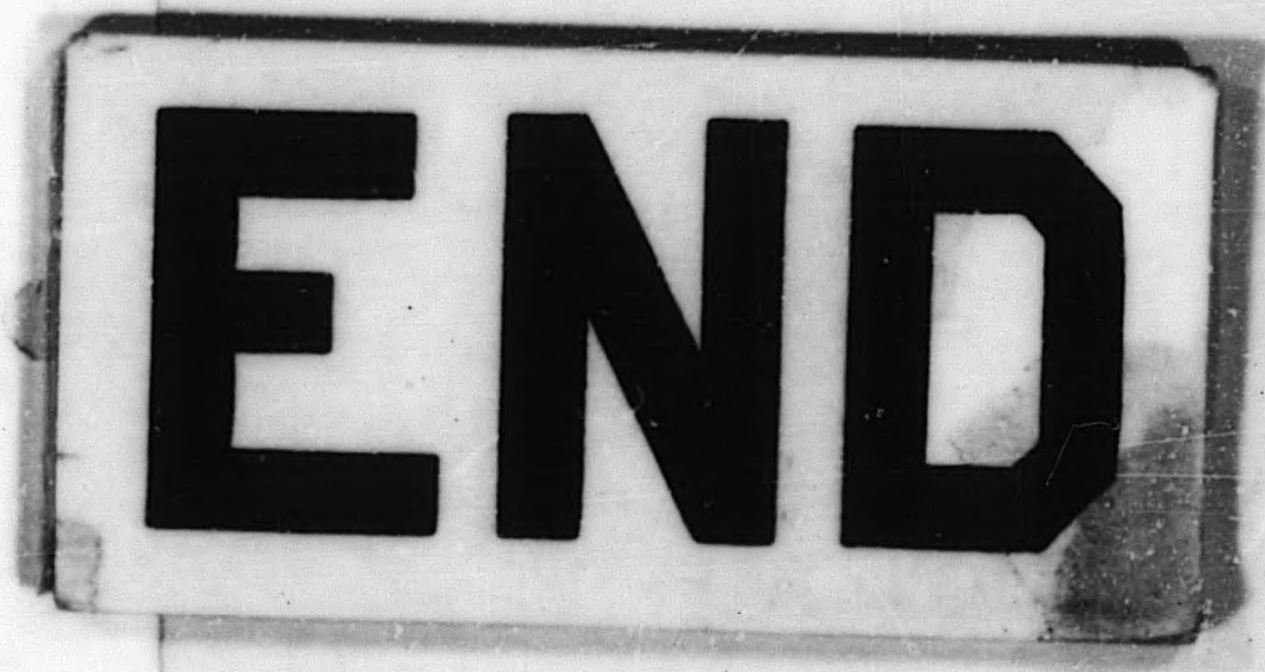

